\title{
Educational Transformation with Virtual Classroom: Integrated between TTF and Social Motivation
}

\author{
Nantinee Soodtoetong ${ }^{1}$, Montean Rattanasiriwongwut ${ }^{2}$ \\ ${ }^{1}$ Faculty of Management Science, Chandrakasem Rajabhat University, Bangkok, Thailand \\ ${ }^{2}$ Faculty of Information Technology and Digital Innovation, King Mongkut's University of Technology \\ North Bangkok, Bangkok, Thailand
}

\begin{abstract}
Many organizations have to adapt to the speed of digital transformation era, namely to accommodate this rapid change. As for educational organization, technologies could support learning, information searching, communication between learners and teachers. It is an important tool to change the learning method from traditional approach that occurs only within the university to online learning that is unlimited to places and times, as a virtual classroom. Especially during the COVID-19 pandemic in the past, many countries have adopted technology to use in teaching and learning. This paper presents a virtual classroom model with Task-Technology Fit to assess the acceptance of the use of appropriate technology in teaching and learning and consider the social influence factors affecting online learning style as well.
\end{abstract}

Keywords - Educational Transformation, Virtual Classroom, Task-Technology Fit, Social Influence.

\section{Introduction}

In an era of changing technologies, operations are important in all sectors, whether business, industry, agriculture, education etc..

DOI: 10.18421/TEM111-56

https://doi.org/10.18421/TEM111-56

Corresponding author: Nantinee Soodtoetong, Faculty of Management Science, Chandrakasem Rajabhat University, Chatuchak, Bangkok, Thailand.

Email: nantinee.s@chandra.ac.th

Received: 28 November 2021.

Revised: 16 February 2022.

Accepted: 21 February 2022.

Published: 28 February 2022.

(cc) BY-NC-ND (C) 2022 Nantinee Soodtoetong \& Montean Rattanasiriwongwut; published by UIKTEN. This work is licensed under the Creative Commons AttributionNonCommercial-NoDerivs 4.0 License.

The article is published with Open Access at https://www.temjournal.com/
There are innovations resulting from the use of new digital technologies that completely destroy the traditional [1], known as digital disruption. It does not mean there are no action happen digitally. On the other hand, it is a changing in technology that causing new innovations. This covers new products, platforms, and business models. This affects the value of goods and services that are already in the market. As can be seen, artificial intelligence is used, high speed communication technology, electronic technology, Internet of Things, big data and data analysis, etc. When these technologies are integrated together, they will result in a more systematic and efficient way which can be used to perform various operations including better solving problems for human beings.

The education sector is also inevitably affected by this technological shift. With the advancement of high-speed communication technology and electronics causing the development of new forms of knowledge presentation including searching for information through electronic devices such as computers, smartphones, etc., there is a result in learning since borderless learning does not limit the boundaries of learners in terms of age, time, place, and the knowledge they want to study. Currently, there are many free and paid online courses such as MOOCs (Massive Open Online Courseware), Coursera, Udemy, Skilllane, Skoodio, Goblish, etc., some of which are certified. The result is that when students finish their studies, they can work immediately.

The development of new platforms and learning models including updating the content to be up-todate and attractive all the time making online courses more popular. As a result, the traditional learning style of classroom learning has been reduced in importance. And it is likely that in the future there will be no teaching at the university level. The lecture in the classroom will be only used to support education. And the role of the teacher will be changed from an instructor to a guide or a supporter 
so that students can think, analyze and synthesize knowledge to apply on their own. Therefore, both educational institutions and teachers have to adjust both their roles and duties and teaching styles to suit this change in technology [2].

In 2020, the whole world and Thailand faced an unexpected situation, the problem of virus COVID19 pandemic through contact. Therefore, educational institutions have adjusted the model of teaching at home by allowing students to study through online media systems or long-distance television, which in addition reduce the spread of the epidemic. Teachers can update lesson plans; learners have more tools to find knowledge. There is a way to contact teachers directly. But the major problem encountered was that most of the teaching styles were one-way communication which has the potential to be mistaken in recognition, unavailability of equipment and communication and parents may not have time to take care of students. Students may be less focused and more interested in the online world than studying. This makes learning in this form of no benefit, causing not so good results for learners.

Therefore, the researcher proposed the idea of using digital technology today to develop and create a virtual classroom with characteristics and environment close to the real classroom (Virtual Learning Environment). There is communication between learners and teachers and between the learners themselves. Assessment of the learning efficiency of the learners is done through a virtual classroom development model. In this paper, we synthesize theories and articles on the development of virtual classrooms and present a model for developing virtual classrooms which are presented in section 2 and 3 , and section 4 is a conclusion respectively.

\section{Background and Notation}

\subsection{Virtual Classroom}

Virtual Classroom (VC) [3], [4], [5], [6], is a technology-based classroom for learning management and simulating the environment to be similar to the real classroom through a computer network for learners to participate in learning. There is interaction between learners and teachers and learners with learners. The teacher will design and simulate the virtual classroom environment to resemble the real place or situation through electronic media and computer network, so that students can access lessons and learn anywhere and at any time without having to attend a real classroom. There are two types of virtual classrooms:
1. Traditional classrooms with regular teaching and learning arrangement. They use telecommunication systems and Internet to broadcast live video and audio to students outside the classroom. Students can follow and listen to the teaching from the computer or TV. They can interact with the teacher and other students in the class. This virtual classroom model relies on the physical education environment that is actually the main teaching and learning management.

2. Virtual classrooms use software to create virtual reality, various electronic media in the presentation of the lesson classroom, activities and network system that allow learners to access lessons anytime, anywhere. It is a real virtual classroom where the classroom environment is created by software called virtual education environment.

Virtual classrooms are often used to manage distance learning to overcome the limitations of distance, time and cost of traveling to school on their own. At present, efforts are being made to establish a virtual university (E-University) [7] by using virtual classroom teaching which is based on various sources (site), there is a management of learning support resources, which are departments, libraries, student service centers, etc., so that learners and students can apply teaching activities together and interact with each other using networking and software to create a real academic community.

The benefits of this virtual classroom in addition to learning anywhere and all the time are that it also gives students the opportunity to choose subjects they are interested in. It increases the knowledge, skills and experience of the learners, support lifelong learning, reduce the burden of travel expenses placement and other expenses. Safety is also provided for learners because learning is simulated in the computer world. To be successful in a virtual classroom, learners have to be responsible, manage their own time in studying, doing activities, doing tests in a timely manner as specified by the teacher.

\subsection{Classroom Design}

The virtual classroom design [8] can be designed to look like this:

1. Learning is fun by designing students to have fun and not stress in the classroom, and they may use JAVA technology to enhance learning. Students are allowed to play games while studying the course content.

2. Multimedia. Various media are used to promote learning. The lessons may contain text, images and sounds. Fingertips can be used to touch various electronic media 
3. Asynchronous learning is a learning design that does not require the teacher to be with the learner at the same time and place. Instructors may create/collect "Online Lessons" that are available for learners to study anywhere, at any time whereas the learner is convenient. The lessons that are available in the system are appropriately selected and can link the lessons learned to other related lessons

4. Electronic library is an electronic library where students can search for what they need from various sources around the world by using tools or programs for searching on the Internet (search engine) or may search for books from various university libraries. And in the library, there may be information services on demand, where students can view information from the monitor (monitor) installed within the library.

In addition, creating a virtual learning environment in the design of a virtual classroom which affects the learning of learners both directly and indirectly. The environment is generally both concrete and abstract. The concrete environment or the physical environment is a condition made by humans such as a building, a place, a table, a chair, a material, a device, or a medium, including things. Natural habitats include trees, plants, landscape, and climate. The abstract environment or the psychological environment is a value system that is an important part of a culture which includes information society groups, knowledge, thoughts, and feelings, thoughts, and attitudes whether it is one's own or someone else's.

The management of a virtual learning environment [9] can be divided into 3 types as follows:

1. Asynchronous Learning is suitable for supplementary learning and learning that learners can learn on their own (self-learning). Students can study subjects through the website at any time. During the course owner's schedule, there will be activities to do. Learners can interact with the instructor at any time, such as asking through the web board via email. In this way, the teacher does not have to be online with the system.

2. Synchronous Learning is teaching as if there are teachers in the classroom and students are widely distributed. Each student has a personal computer to stay on the internet and register for that course. In this way, the teacher will teach by following the learner's learning. There is immediate contact with students, such as Chat, which provides a fixed time online for learners and teachers to meet in a virtual classroom.
3. Collaborative Learning. This type of teaching involves collaboration between learners and teachers with specific software that everyone can use together, such as whiteboard or virtual reality software. Students and teachers can interact and work together.

The communication that occurs in the virtual classroom can be done as follows:

1. E-mail is used to send homework and assignment.

2. Web board is used to communicate between learners and teachers, and learners with learners without having to be at the same time and place.

3. Conversation on the network (Chat) is used to communicate between learners and teachers and learners with learners by chatting online (real-time).

4. Conference is used to communicate between learners and teachers and learners with learners via video camera. It looks like a lecture for students to listen to as if they were studying in a real classroom.

5. Electronic Homework Book is a virtual identification book of learners used to submit assignments that the teacher has assigned, such as reports or homework.

\subsection{Social Influence}

Social influence [10] refers to the behavior of a person influencing another person. The influence on thoughts, beliefs and feelings can be divided into 3 types as follows:

1. Sanction for a person to perform duties or behaviors as defined by society. Enforcement includes penalties and rewards.

2. Norm, customs, customs, customs and laws when a person is in a society, it is necessary to try to behave in order to be accepted by society. In addition, the behavior of a person in accordance with social etiquette and customs is part of the social influence.

3. Value Orientation: People accept and act willingly. It is partly because of the willingness to see the value in it. The stimuli directly or indirectly influence the behavior of individuals in society. They cause to follow or imitate.

\subsection{Task-Technology Fit}

Task-Technology Fit (TTF) describes the user acceptance of technology when the technology is appropriate for the task and can make the task more efficient [11]. There are two key factors affecting the suitability between task and technology. Factors are Task Characteristics and Technology Characteristics. In addition, the suitability of the job and technology also affects the perceived behavior which makes technology useful. Utilization and the potential of the performance impacts are as shown in Figure 1. 


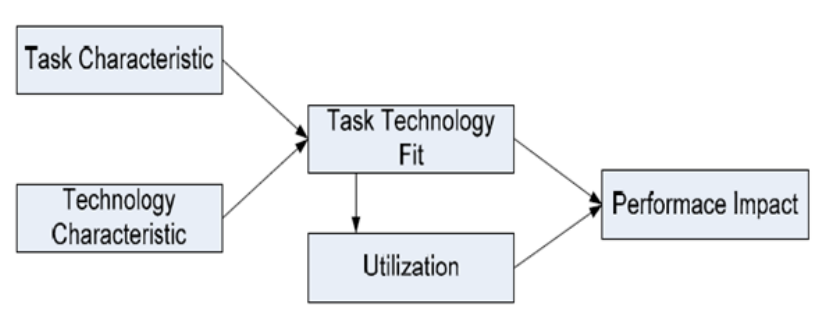

Figure 1. Task-Technology Fit [11]

Due to the characteristics of different types of work, individuals will also have different degrees of acceptance of technology dependency. When the technology that is chosen is appropriate for the job, it results in a person's perception of the benefits and improving the potential of the job and acceptance of the use of that technology.

\section{Methodology}

The objective of this paper aims to:

1. Synthesize factors affecting the development of a virtual classroom model to develop learners' potential;

2. Develop a virtual classroom model to develop students' potential.

By synthesizing articles and related research, we can determine the factors affecting the development of a virtual classroom model. To support the formulation of research hypotheses as follows:

\subsection{The use of Technology Effect the Virtual Classroom}

Southgate et al. [12] investigated the use of virtual reality technology in science and computing classes in low-income schools. It was found that the students were more interested in learning and understood the lesson. Due to investment restrictions equipment or a place to do teaching cannot be provided. The use of virtual reality technology helps simulate real situations for learners to know and have direct experience with that situation and even more improved understanding of the lesson and learning outcomes.

Kerimbayev et al. [13] has presented research on a virtual classroom using LMS Moodle in combination with communication technologies such as e-mail, teleconferencing and virtual reality technologies such as Daydream, Vive VR to create virtual classrooms trial with undergraduate students. The results showed that the proposed system can help learners to think critically, have judgment in making decisions, which is more assertive from result showing the success of using the system is $86 \%$.

Loureiro and Bettencourt [14] studied the use of 3D technology to create a virtual classroom to fulfill the needs of students and facilitate collaborative learning. This virtual classroom can create interactions between students and teachers and activities in the classroom without physical limitations like a real classroom. In the research, the technique of games and 3D technology is proposed to determine the identity of the learner under the supervision of the teacher.

It can be concluded that the choice of technology affects the development of the virtual classroom. From the research, it can be seen that the technology used in communication, virtual reality technology, 3D technology can be combined together to create a virtual classroom. Therefore, the hypothesis was set for the study as follows:

H1: The use of technology effect the virtual classroom.

\subsection{The Learning Design Effect the Virtual Classroom}

Blume et al. [15] investigated the design of virtual learning for children with attention-deficit hyperactivity disorder or ADHD using virtual reality technology. The researcher believes that the distance between the learner and the teacher affects the level of interest in learning. Therefore, a virtual classroom has been designed with virtual reality technology to make the learners feel that they are sitting close to the teacher causing more interest in learning. However, this research has limitations that cannot be applied to general learners. Success depends on the degree of inattention of the learners themselves.

Amornchai et al. [16] designed a learning model using a virtual classroom commentary approach. Expressing opinions will help learners develop important skills, especially analytical reasoning skills. Learners can freely explain, analyze, calculate and summarize their knowledge just like learning in a real classroom with teachers acting to supervise and design activities

$\mathrm{Xu}$ et al. [17] conducted research to improve the efficiency of e-learning systems in combination with artificial intelligence systems in order to optimize individual learner learning by offering a personalized e-learning effectiveness model. The results showed that the use of artificial intelligence system to analyze learners' characteristics affects the efficiency of the e-learning system that is suitable for the learners and increase the learning efficiency of learners

It can be concluded that the teacher is an important person in creating activities for learning which comprises the lesson assignments, projects, and environments suitable for the course, including the use of artificial intelligence systems that help in analyzing the behavior of learners as well. This help us to develop and improve learning styles to suit individual learners. Therefore, the hypothesis was set for the study as follows:

\section{H2: The learning effect the virtual classroom.}




\subsection{The Social Influence Effect the Virtual Classroom}

Miloševic' et al. [18] investigated the use of social media. An example is the use of Facebook as a tool to create a virtual classroom. The variables that influenced learning motivation and the use of social media as a learning tool were studied. It was found that using Facebook as a virtual classroom can create and develop communication between learners and teachers, commenting in class news announcements about learning and help other classmates in the work assigned.

In conclusion, social media can be used as a tool to create a virtual classroom. By using the media platform, social media can also be used as a communication channel between students and teachers, learners with learners, and it is an area where students can express their opinions without limitation Therefore, the hypothesis was set for the study as follows:

H3: The social influence effect the virtual classroom.

\subsection{Task Characteristic and Technology Characteristic Effect the Virtual Classroom}

Cruz [19] suggests that learning is a form of work that uses computer technology and communication technology to manage teaching and learning successfully and effectively. Therefore, research has been conducted on how information technology in learning can help individuals to improve their competency by applying work and technology suitability theory by reviewing the relevant literature.

Saidin et al. [20] studied the effects of the Internet on online training using the theory of suitability between work and technology. The format of training in Malaysia has shifted to online training but, using the Internet for training can affect performance. Therefore, this effect was studied using an online survey. The results showed that the Internet had a positive direct and indirect impact on online training.

Yadegaridehkordi et al. [21] investigated the factors that play an important role in predicting the use of cloud-based collaborative learning among learners with the theory of job and technology suitability by completing an online questionnaire. The results showed that cloud applications with more privacy, mobility, and collaboration characteristics are more appropriate to support collaborative learning. And the suitability between work and technology directly affects user adoption of the cloud.

In conclusion, the use of technology in the virtual classroom, TTF positively effects the use of user acceptance. Therefore, the assumptions were formulated in the study as follows:

H4: Task Characteristic and Technology Characteristic effect the virtual classroom.

\subsection{The Virtual Classroom Effect the Learning Performance}

Kultawanich et al. [22] proposed a knowledgelinking model using cloud-based virtual classrooms to improve information literacy and information literacy self-efficacy for undergraduate students. Research has shown that virtual classrooms are among the most powerful tools for effective online learning and the use of them develop social interactions using cloud-based tools and platforms.

Mathew et al. [23] researched the use of virtual classrooms with situational theory in the course introduction to public relations to predict success in online learning. It was found that after the trial of the system, more students were interested in enrolling. Reduced incomprehensibility in the course occurred due to the help desk system and information related to learning that allows students to find information and contact the teacher at all times. The success was measured by the results of the end of the semester test, which showed improvement in academic performance.

Glava and Glava [24] offer a virtual classroom system called BSCW (Basic, Smart, Cooperate Worldwide) and trial it with preschool and elementary teachers. This system is specially designed to facilitate the effective management of teaching and learning of learners using collaborative learning tools. It is assumed that the use of a virtual classroom model on the BSCW platform will help to develop students' skills necessary for learning. After the end of the experiment, the researchers interviewed the subjects and found that $\mathrm{BSCW}$ is a system that helps train skills and has resources to support learning. In addition, simulations give learners the confidence in their transfer skills, which are essential for their future teacher roles.

It can be concluded that the virtual classroom developed according to the defined variables is the use of technology and learning design. It has an effect on learning by increasing the learning efficiency of the learners. Learners are more interested and willing to learn. It can also help practice thinking skills and communication decision. Therefore, the hypothesis was set for the study as follows:

H5: The virtual classroom effects the learning performance.

A summary of references of related research to support the determination of research hypothesis is shown in Table 1. 
Table 1. Summary of research references in supporting research hypothesis.

\begin{tabular}{|c|c|}
\hline Hypothesis & Related Research \\
\hline $\begin{array}{l}\text { H1: The use of technology effect } \\
\text { the virtual classroom }\end{array}$ & {$[12],[13],[14]$} \\
\hline $\begin{array}{l}\mathrm{H} 2 \text { : The learning effect the } \\
\text { virtual classroom }\end{array}$ & {$[15],[16],[17]$} \\
\hline $\begin{array}{l}\text { H3: The social influence effect } \\
\text { the virtual classroom }\end{array}$ & [18] \\
\hline $\begin{array}{l}\text { H4: Task Characteristic and } \\
\text { Technology Characteristic effect } \\
\text { the virtual classroom. }\end{array}$ & [19], [20], [21] \\
\hline $\begin{array}{l}\text { H5: The virtual classroom effect } \\
\text { the learning performance }\end{array}$ & {$[22],[23],[24]$} \\
\hline
\end{tabular}

From the study of concepts, theories and related research, a structural equation model can be developed as a virtual classroom model to increase learners' efficiency as shown in Figure 2.

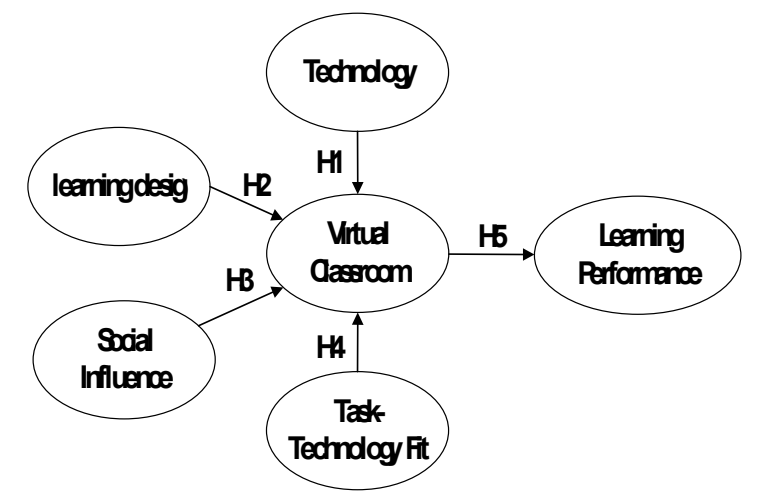

Figure 2. Proposed Model

\section{Conclusion}

This paper presents a virtual classroom model to improve learner performance. By review theory and related research, we have synthesized factors influencing the creation of a virtual classroom together with Task-Technology Fit theory in the acceptance of learners' use of the virtual classroom. Moreover, we considered social influence factors. The results of the study were then used to formulate the hypothesis of the research in order to develop them into a virtual classroom additionally.

\section{References}

[1]. Penprase, B. E. (2018). The fourth industrial revolution and higher education. Higher education in the era of the fourth industrial revolution, 10, 978981.

[2]. Mano, P. (2019). The impact of digital disruption to the education. Journal of Industrial Education, 18(1), 1-6.

[3]. Hiltz, S. R., \& Wellman, B. (1997). Asynchronous learning networks as a virtual classroom. Communications of the ACM, 40(9), 4449.

[4]. Hiltz, S. R. (1986). The "virtual classroom": Using computer-mediated communication for university teaching. Journal of communication, 36(2), 95-104.

[5]. Turoff, M. (1995). Designing a virtual classroom. International Journal of Educational Telecommunications, 1(2), 245-262.

[6]. Rizzo, A. A., Buckwalter, J. G., Bowerly, T., Van Der Zaag, C., Humphrey, L., Neumann, U., ... \& Sisemore, D. (2000). The virtual classroom: a virtual reality environment for the assessment and rehabilitation of attention deficits. CyberPsychology \& Behavior, 3(3), 483-499.

[7]. Ismail, R., Safieddine, F., \& Jaradat, A. (2019). Euniversity delivery model: handling the evaluation process. Business Process Management Journal, 25(7), 1633-1646.

[8]. Rufai, M. M., Alebiosu, S. O., \& Adeakin, O. A. S. (2015). A conceptual model for virtual classroom management. International Journal of Computer Science, Engineering and Information Technology, 5(1), 27-32.

[9]. Ellaway, R., Dewhurst, D., \& McLeod, H. (2004). Evaluating a virtual learning environment in the context of its community of practice. ALT-J, 12(2), $125-145$

[10]. Argo, J. J. (2020). A contemporary review of three types of social influence in consumer psychology. Consumer Psychology Review, 3(1), 126140.

[11]. Goodhue, D. L., \& Thompson, R. L. (1995). Tasktechnology fit and individual performance. MIS quarterly, 213-236.

[12]. Southgate, E., Smith, S. P., Cividino, C., Saxby, S., Kilham, J., Eather, G., ... \& Bergin, C. (2019). Embedding immersive virtual reality in classrooms: Ethical, organisational and educational lessons in bridging research and practice. International Journal of Child-Computer Interaction, 19, 19-29.

[13]. Kerimbayev, N., Nurym, N., Akramova, A., \& Abdykarimova, S. (2020). Virtual educational environment: interactive communication using LMS Moodle. Education and Information Technologies, 25(3), 1965-1982.

[14]. Loureiro, A., \& Bettencourt, T. (2011). The Extended Classroom: meeting students' needs using a virtual environment. Procedia-Social and Behavioral Sciences, 15, 2667-2672. 
[15]. Blume, F., Göllner, R., Moeller, K., Dresler, T., Ehlis, A. C., \& Gawrilow, C. (2019). Do students learn better when seated close to the teacher? A virtual classroom study considering individual levels of inattention and hyperactivity-impulsivity. Learning and Instruction, 61, 138-147.

[16]. Amornchai, P., Songkhla, J. N., \& Sujiva, S. (2015). An argument performance task in a virtual classroom for enhancing graduate students' analytical reasoning. Procedia-Social and Behavioral Sciences, 174, 1031-1035.

[17]. Xu, D., Huang, W. W., Wang, H., \& Heales, J. (2014). Enhancing e-learning effectiveness using an intelligent agent-supported personalized virtual learning environment: An empirical investigation. Information \& Management, 51(4), 430-440.

[18]. Milošević, I., Živković, D., Arsić, S., \& Manasijević, D. (2015). Facebook as virtual classroom-Social networking in learning and teaching among Serbian students. Telematics and Informatics, 32(4), 576-585.

[19]. Cruz, A. P. (2009, December). Task-Technology Fit and Performance in Learning. In 2009 International Conference on Information and Multimedia Technology (pp. 82-85). IEEE.
[20]. Saidin, S. S., Iskandar, Y. H. P., \& Dahlan, N. (2017, November). The mediating role of internet addiction on the relation between task technology fit and performance impact in online training context. In 2017 IEEE Conference on e-Learning, eManagement and e-Services (IC3e) (pp. 133-137). IEEE.

[21]. Yadegaridehkordi, E., Iahad, N. A., \& Ahmad, N. (2014, June). Task-technology fit and user adoption of cloud-based collaborative learning technologies. In 2014 International Conference on Computer and Information Sciences (ICCOINS) (pp. 1-6). IEEE.

[22]. Kultawanich, K., Koraneekij, P., \& Na-Songkhla, J. (2015). Development and validation of the information literacy assessment in connectivism learning environment for undergraduate students. Procedia-Social and Behavioral Sciences, 174, 1386-1390.

[23]. Kruger-Ross, M. J., \& Waters, R. D. (2013). Predicting online learning success: Applying the situational theory of publics to the virtual classroom. Computers \& Education, 61, 176-184.

[24]. Glava, C. C., \& Glava, A. E. (2011). On-line learning platforms as virtual classrooms. Case study of initial primary teachers training at Babes-Bolyai University of Cluj-Napoca, Romania. Procedia Computer Science, 3, 672-676. 